\title{
Using Spatio-Temporal Modeling for Exposure Assessment in an Investigation of Fine Particulate Air Pollution and Cardiovascular Mortality
}

\author{
Arvind Dabass $^{\mathrm{a}}$, Evelyn O. Talbott ${ }^{\mathrm{a}}$, Richard A. Bilonick ${ }^{\mathrm{b}, \mathrm{c}}$, Judith R Rager $^{\mathrm{a}}$, Arvind Venkat ${ }^{\mathrm{d}}$, \\ Gary M. Marsh ${ }^{\mathrm{c}}$, Chunzhe Duan ${ }^{\mathrm{a}}$, Tao Xue \\ anniversity of Pittsburgh, Graduate School of Public Health, Department of Epidemiology, 130 \\ DeSoto Street, Pittsburgh, Pennsylvania,15261 USA \\ ${ }^{b}$ University of Pittsburgh, School of Medicine, Department of Ophthalmology, 203 Lothrop \\ Street, Pittsburgh, Pennsylvania, 15213 USA \\ ${ }^{c}$ University of Pittsburgh, Graduate School of Public Health, Department of Biostatistics, 130 \\ DeSoto Street, Pittsburgh, Pennsylvania,15261 USA \\ ${ }^{\mathrm{d}}$ Allegheny Health Network, Department of Emergency Medicine, 320 E North Avenue, \\ Pittsburgh, Pennsylvania,15212 USA \\ ${ }^{\mathrm{e}}$ University of Pittsburgh, Graduate School of Public Health, Environmental and Occupational \\ Health, Bridgeside Point 1, 100 Technology Drive, Pittsburgh, Pennsylvania, 15219, USA \\ Corresponding Author: Evelyn O. Talbott DrPH, MPH \\ A526 Crabtree Hall, 130 DeSoto Street \\ Pittsburgh, PA 15261 \\ Phone: 412-624-3074 \\ Fax: 412-624-7397 \\ Email: eot1@pitt.edu
}

Short Title: $\mathrm{PM}_{2.5}$ Air Pollution and Cardiovascular Mortality

(C) 2016. This manuscript version is made available under the Elsevier user license http://www.elsevier.com/open-access/userlicense/1.0/ 
ABSTRACT Background: U.S. urban air quality has improved dramatically over the past decades. We evaluated acute effects of fine particulate matter $\left(\mathrm{PM}_{2.5}\right)$ on cardiovascular (CVD) mortality among residents of Allegheny County in SW Pennsylvania (1999-2011) using spatiotemporal modeling of air pollutants (AP) to reduce misclassification error in exposure assessment. Methods: Spatio-temporal kriging of daily $\mathrm{PM}_{2.5}$ and ozone $\left(\mathrm{O}_{3}\right)$ was used to produce daily exposure estimates at the residence ZIP code. Time-stratified case-crossover analysis was conducted to examine short-term effects of $\mathrm{PM}_{2.5}$ on CVD mortality, adjusting for $\mathrm{O}_{3}$ and apparent mean temperature. We studied both single and distributed lags for days 0-5. All CVD mortality and subcategories of ischemic heart disease (IHD), acute myocardial infarction, cerebrovascular disease, peripheral vascular disease (PVD), heart failure and cardiac arrhythmia were examined. Results: A total of 62,135 deaths were identified. We found significant associations of $\mathrm{PM}_{2.5}$ with IHD and PVD mortality at lag day 5: $(2.1 \%(95 \% \mathrm{CI}, 0.2 \%-4.1 \%)$ and $(7.6 \%, 95 \% \mathrm{CI}, 0.05 \%$ 15.7\%) per $10 \mu \mathrm{g} / \mathrm{m} 3$ increase of $\mathrm{PM}_{2.5}$ in single lag models and distributed lag models. There were no statistically significant associations with $\mathrm{PM}_{2.5}$ for any of the outcomes for lag days 0-4 or distributed lag days 0-4. Conclusions: The application of finer scale geographically resolved AP exposures made it possible to study acute effects of $\mathrm{PM}_{2.5}$ on CVD mortality in a large metropolitan area. Our study results demonstrated the continued presence of a dose response relationship of increased risk of CVD mortality within this lower range of $\mathrm{PM}_{2.5}$ exposure.

Key Words

1. Cardiovascular; 2. $\mathrm{PM}_{2.5}$; 3. Air Pollution; 4. Fine Particulate Matter 5. Health Effects 
Funding: This study was funded by the Electric Power Research Institute EP-P29581/C13936 and EP-P46301/C19907. The feasibility study for PARIES was funded by the U.S. Department of Energy contract DE-PS26-04NT42066. Additional funding has been provided by the Allegheny County Health Department (Pittsburgh, Pennsylvania)

Competing financial interest declaration: The authors declare they have no actual or potential competing financial interests. 


\section{Introduction and Background}

Brook RD et al. as part of a scientific statement from the AHA, (American Heart Association) extensively reviewed the available evidence to study the relationship of PM air pollution and CVD. They summarized that there is a small, yet consistent association between increased cardiovascular disease mortality and short term elevations in $\mathrm{PM}_{10}$ and $\mathrm{PM}_{2.5}$. Studies show that for every $10 \mu \mathrm{g} / \mathrm{m}^{3}$ elevation in $\mathrm{PM}_{2.5}$ during the preceding 1 to 5 days, there is increase of $0.4 \%$ to $1.0 \%$ in daily cardiovascular mortality (citation). Hospital admissions due to CVD were also elevated in response to daily changes in PM levels. The AHA statement also concluded that there is a strong evidence of short term effects of $\mathrm{PM}_{2.5}$ on ischemic heart disease morbidity and mortality, moderate (yet growing) evidence for heart failure and ischemic stroke, and modest or mixed evidence for peripheral vascular and cardiac arrhythmia/arrest. (Brook RD et al. 2010)

Since the AHA statement, several additional studies have been conducted in the United States and other parts of world which have examined the relationship of short-term $\mathrm{PM}_{2.5}$ exposure with CVD mortality. In a study conducted in New York, Ito et al. found that $\mathrm{PM}_{2.5}$ was associated with CVD mortality in the warm season at lag day 0 (\% Excess Risk $(\mathrm{ER})=2.0 \% ; 95 \%$ confidence interval (CI), 0.7-3.3 per $10 \mu \mathrm{g} / \mathrm{m} 3)$; and at lag day 1 (1.9\%; 95\% CI, 0.8-3.1 per 10 $\mu \mathrm{g} / \mathrm{m} 3)$ and in the cold season at lag day 1 (1.0\%; 95\% CI, -0.1 to 2.2 per $10 \mu \mathrm{g} / \mathrm{m} 3$ ) (Ito et al. 2011). Zhou et. al. found a significant positive association for cumulative effect from lag day 0 to 2 for $\mathrm{PM}_{2.5}$ for all-cause and cardiovascular mortality during the warm season in Detroit, suggesting a role of secondary pollutants; in contrast, Seattle showed positive associations in the winter. (Zhou et al. 2011)

Shang et.al conducted a meta-analysis of time series studies from China during 1990-2012 and found that each $10 \mu \mathrm{g} / \mathrm{m}^{3}$ increase in $\mathrm{PM}_{2.5}$ was associated with a $0.44 \%$ (95\% CI: 0.33-0.54) 
increase in CVD mortality (Shang et al. 2013). The associations for $\mathrm{PM}_{10}$ were similarly strong. In 2013, Shah et. al conducted a meta-analysis of global studies conducted during 1984-2012 that examined the relationship of daily levels of particulate matter and gaseous pollutants with heart failure hospitalizations and death (Shah et al. 2013). They found that increases in particulate matter concentration were associated with heart failure hospitalization or death $\left(\mathrm{PM}_{2.5}, 2.12 \%\right.$ per 10 $\mu \mathrm{g} / \mathrm{m}^{3}, 95 \% \mathrm{CI}: 1.42-2 \cdot 82 ; \mathrm{PM}_{10}, 1.63 \%$ per $10 \mu \mathrm{g} / \mathrm{m}^{3}, 95 \%$ CI: $\left.1.20-2.07\right)$. Strongest associations were seen on the day of exposure, with more persistent effects for $\mathrm{PM}_{2.5 .}$. Samoli et al.conducted meta-regression of time series in 10 European Mediterranean metropolitan areas (Samoli et al. 2014). They found a statistically significant increase in cardiac deaths of $1.33 \%$ (95\% CI: 0.27 $2.40 \%$ ) for a $10 \mu \mathrm{g} / \mathrm{m}^{3}$ increase in six days' $\mathrm{PM}_{2.5}$ exposure.

Five studies to date have examined the relationship between daily $\mathrm{PM}_{2.5}$ and mortality in the greater Pittsburgh (Allegheny County, PA area). Chock et.al. conducted a time series from 1989-1991 and found statistically significant results for $\mathrm{PM}_{10}$ with daily non-accidental mortality for age $<75$ in 0- lag model (Chock et al. 2000). However, due to small signal to noise ratio, they could not credibly ascertain the relative association of $\mathrm{PM}_{2.5}$ and mortality. Franklin et.al in a multicity analysis, found a statistically significant association between lag day $1 \mathrm{PM}_{2.5}$ and allcause mortality in Pittsburgh (Franklin et al. 2007) In another multicity analysis, Franklin et.al found an overall statistically significant association of $\mathrm{PM}_{2.5}$ and non-accidental deaths and CVD mortality but Pittsburgh specific results were not available (Franklin et al. 2008).

Two investigations focused on cardiovascular and respiratory morbidity and mortality in the Pittsburgh -region (Mazumdar and Sussman 1983), (Arena et al. 2006). The first used coefficient of haze, an early marker of total suspended particulates, $\mathrm{SO}_{2}$ and weather variables at three separate monitor locations (1972-77) to study the relationship of cardiovascular and respiratory mortality in Allegheny County residents. Results indicated a possible association 
between heart disease mortality/morbidity and same day particulate levels. (Arena et al. 2006) considered daily cardiopulmonary hospitalizations in people 65 years and older in Allegheny County for the period 1995-2000 and countywide average $\mathrm{PM}_{10}$ measures. Using generalized additive models (GAM), a Poisson regression model was fit to the number of daily admissions using predictor variables: 0- 5 lag days of $\mathrm{PM}_{10}$, daily temperature and humidity, day of the week, and time. There were eight monitoring locations, and average values were computed for $\mathrm{PM}_{10}$ using all eight for a daily average. Their findings suggest that there was a positive association of $\mathrm{PM}_{10}$ with hospital admissions, and the effect is related to current-day of the hospitalization. This translates into an increase of $0.0609 \%$ (95\% CI 0.0263- 0.0955) in cardio- pulmonary hospital admissions above that which is predicted by seasonal trend, daily temperature and relative humidity, and day of the week for a 1 microgram increase in $\mathrm{PM}_{10} / \mathrm{m} 3(.6 \%$ per $10 \mathrm{ug} / \mathrm{m} 3)$.

In summary, a number of studies have been conducted in the Pittsburgh (Allegheny County) area over the past several decades to examine the short term effects of particulate matter on morbidity and mortality. None to date, however, has published results of the short term association of $\mathrm{PM}_{2.5}$ and cardiovascular disease mortality specifically. Also, none have examined subgroups of cardiovascular mortality (e.g., ischemic heart disease, cerebrovascular disease).

One of the most common limitations cited by authors of each of these investigations is the availability of only a few monitors for exposure assessment over a large area and thus likely creating increased exposure error with distance from the monitoring site. In addition, these investigations largely did not consider specific subgroups of outcomes within the general category of cardiovascular mortality which can have important public health implications. 
Allegheny County located in SW PA has unique characteristics for studying the effects of environmental exposures. The area has long been a seat of heavy industry in the northeastern corridor of the United States. The Pittsburgh area ranks as the fourth highest in air pollution levels in the country and is the home to the country's largest coke oven operation, a significant emitter of particulates and metals. The county is characterized by complex terrain, periods of heavy traffic, large industrial sources, and frequent inversion events. This combination of topography, meteorology, and emission sources results in significant spatial variability in many pollutant concentrations, including fine particulate matter $\left(\mathrm{PM}_{2.5}\right)$ and black carbon (BC). Tunno et al. in Pittsburgh, designed a 2-year monitoring campaign to capture spatial variation in $\mathrm{PM}_{2.5}$ and $\mathrm{BC}$. Inversion-focused integrated monitoring (0600-1100 hours) was performed during year 1(20112012) and compared with 1-week 24-h integrated results from year 2 (2012-2013) (Tunno et al. 2016). They found stronger spatial contrasts in $\mathrm{PM}_{2.5}$ and $\mathrm{BC}$ using inversion-focused sampling, suggesting greater differences in peak exposures across urban areas than is captured by most integrated saturation campaigns. Temporal variability, commercial and industrial land use, PM2.5 emissions, and elevation were significant predictors as well as peak hours suggesting that regional levels of $\mathrm{PM}_{2.5}$ are not always be as sensitive or predictive.

The primary goal of the present study was to examine the acute effects of fine particulate matter $\left(\mathrm{PM}_{2.5}\right)$ on cardiovascular (CVD) mortality among residents of Allegheny County in SW Pennsylvania (1999-2011) using spatio-temporal modeling of air pollutants (AP) to reduce misclassification error in exposure assessment. We employed spatio-temporal kriging on a fine grid over the county to estimate exposure daily levels of $\mathrm{PM}_{2.5}$ and ozone for each of the 126 ZIP code tabulation areas (ZCTAs) in Allegheny County, Pennsylvania from 1999-2011. These daily exposure levels were used in a time-stratified case-crossover study design to examine the shortterm association of ambient $\mathrm{PM}_{2.5}$ with the risk of death due to $\mathrm{CVD}$, adjusting for ozone $\left(\mathrm{O}_{3}\right)$ and 
apparent mean temperature. We also sought to identify vulnerable population subgroups defined by sociodemographic characteristics, location at the time of death and time of year (season) of death who may be more sensitive to the short-term effects of $\mathrm{PM}_{2.5}$.

\section{Materials and Methods}

As of 2010 (2010 Census 2010), the population of Allegheny County was 1.2 million of whom 305,000 reside in the city of Pittsburgh. The racial distribution for Allegheny County is primarily white (81.0\%) and African American (13.4\%).

\section{Mortality Data}

Mortality data for Allegheny County residents for the period January 1, 1999-December 31, 2011 were obtained from the Pennsylvania Department of Health Vital Statistics Division. These data were collected from death certificate information and included for each death, the date and cause of death (International Classification of Diseases (ICD)-10), sex, age, race, education, location at the time of death, ZIP code of residence, county and state of death. We classified natural cause mortality data into all diseases of the circulatory system (ICD-10, I00-I99), ischemic heart disease (ICD-10, I20-I25), acute myocardial infarction (ICD-10, I21), cerebrovascular disease (ICD-10, I60-69), peripheral vascular disease (ICD-10, I70-79), heart failure (ICD-10, I50) and cardiac arrhythmias (ICD-10, I47-I49). We also considered effect modification by stratifying the mortality data by age ( $<80$ and $\geq 80$ years), educational level $(<12,12,>12$ years), race (white, black, and other), location at the time of death (hospital, nursing home, and outside of hospital or nursing home) and season (cold season defined as October-March and warm season defined as April-September). Age was categorized as $<80$ and $80+$ to reflect that a significant portion of cardiovascular deaths occur to the very old ( $60 \%$ in this study) and that there is evidence that the very old may be significantly more susceptible to short term effects of $\mathrm{PM}_{2.5}$ (Haley et al. 2009) 


\section{Weather Data}

Meteorological variables of daily mean air temperature and dew point temperature were available from the Pittsburgh International Airport. We calculated apparent air temperature (Steadman 1979) as a combination of air temperature and dew point temperature to take into account the health effects of hot, humid days. The following formula was used to calculate apparent mean temperature:

Apparent mean temperature $\left({ }^{\circ} \mathrm{C}\right)=-2.653+0.994 \times$ Mean air temperature $\left({ }^{\circ} \mathrm{C}\right)+0.0153 \times$ Dew point temperature $\left({ }^{\circ} \mathrm{C}\right)^{2}$

\section{Air Pollution Data and Exposure Estimation}

The environmental data for $\mathrm{PM}_{2.5}$ and $\mathrm{O}_{3}$ was obtained for routine air monitors which were located mainly in western Pennsylvania and the eastern part of Ohio from 1999 to 2011. These monitors were from multiple networks, including the Air Quality System (AQS), the Pittsburgh Air Quality System (PAQS), the Steubenville Comprehensive Air Monitoring Program (SCAMP), and the Clean Air Status and Trends Network (CASTNET). Figure 1 shows the placement of the monitors used in the study. There were 12 monitors within the county and 10 just outside the periphery with an additional 26 in the Ohio, Weirton, WV area (downwind) and surrounding PA counties. For each pollutant, exposure was estimated for each point in a fine square grid using spatio-temporal kriging based on a space-time product-sum covariance function (Cressie and Wikle 2011; De Iaco et al. 2002). This method has been widely used to interpolate spatio-temporal measurements of air pollutants.

The first step in the process of conducting the spatio-temporal kriging involved describing the spatio-temporal correlation between measurements made at different locations and/or on 
different days using an empirical space-time variogram. In the second step, we assumed a nonseparable stationary auto-correlation for our measurements and used a product sum of two Matern functions to fit to the empirical variogram. A Matern function is a very flexible way to model the statistical covariance structure between two points (Minasny and McBratney 2005). In the third step, spatio-temporal kriging was used to construct a fine grid (one kilometer by one kilometer) of exposure estimates for $\mathrm{PM}_{2.5}$ and $\mathrm{O}_{3}$ using the space-time variogram model to produce optimal interpolation weights. The resulting exposure estimates at each grid point depend on measurements that are primarily near-by in space and within a few days before and after the prediction date.

In the last step, for a given date and ZCTA, all exposure estimates falling within the given ZCTA were averaged. ZIP Code Tabulation Areas (ZCTAs) are generalized areal representations of United States Postal Service (USPS) ZIP Code service areas (US Census-ZCTA). ZIP Codes represent groups of delivery points (addresses), designed for efficiency of delivery. In most cases ZIP Codes resemble spatial areas since they comprise contiguous streets and address ranges. The final result was a daily time series of exposure estimates for each ZCTA. The overall accuracy of spatio-temporal kriging was evaluated using 10 -fold cross-validation. The amount of variance explained by $\mathrm{PM}_{2.5}$ and $\mathrm{O}_{3}$ spatio-temporal kriging prediction models was $74.8 \%$ and $87.9 \%$, respectively. These daily exposure estimates of $\mathrm{PM}_{2.5}$ mass concentration and $\mathrm{O}_{3}$ concentration at each ZCTA level were "linked" to the deaths (cases) based on date of death and the residential ZIP code provided on the death certificate. For a small number of individuals the ZIP code of residence on the death certificate did not correspond with a ZCTA. These individuals were excluded from the study.

For mapping the location of the sampling sites, we used the R statistical programming software (Version 3.3.1, R Core Team, 2016) along with the R packages ggmap (Version 2.6.1; 
(Kahle and Wickham 2013), ggplot2 (Version 2.0.0; (Wickham 2009), ggsn (Version 0.3.1;

(Baquero 2016), ggthemes (Version 3.2.0; (Arnold et al. 2016), maps (Version 3.0.2; (Becker and Wilks 2016), plyr (Version 1.8.3; (Wickham 2011), and rgdal (Version 1.1-10; (Bivand et al. 2016).

\section{Statistical analysis}

We used a case-crossover design (Maclure 1991). In this method each case acts as its own control. This approach offers the advantage of controlling for potential confounding from fixed or slowly varying individual-level characteristics. We used time-stratified referent selection, in which time is divided into fixed strata and the days in each stratum are considered for referents. Control days were matched on the same day of week in the same calendar month and year when a death (i.e., case) occurred. Each case had either three or four control days. The level of ambient $\mathrm{PM}_{2.5}$ in the time period before a death was compared with the $\mathrm{PM}_{2.5}$ at referent time periods.

$\mathrm{PM}_{2.5}$ mass concentration effects were examined with single-day lags (0-5 day) and unconstrained distributed lags by cause-specific mortality. Lag day 0 represents exposure on the same day as death; lag day 1 represents exposure on the previous day, and so on. Individual models were constructed with just one particular lag (i.e., the coefficients for the other lags were constrained to zero). Unconstrained distributed lag models contain all six lag terms simultaneously in the model; so, for example, the unconstrained distributed lag model for maximum lag day 5 will contain all lag terms from lag day 0 to lag day 5 . All models included ozone and apparent mean temperature at the same lag as the $\mathrm{PM}_{2.5}$ mass concentration in single-day lag models or the same distributed lags in unconstrained distributed day lag models. We fitted conditional logistic regression models using PROC PHREG in SAS 9.3 (SAS Institute, Cary, NC, USA). Results were expressed as the percentage change in risk of mortality per $10 \mu \mathrm{g} / \mathrm{m}^{3}$ increase for $\mathrm{PM}_{2.5}$. To 
examine effect modification (i.e., interaction effects), we separately fitted models with an interaction term for $\mathrm{PM}_{2.5}$ mass concentration and potential effect modifier (age, gender, race, education, season, and location at the time of death). We compared the fit of the models (single versus distributed models using the Akaike Information Criterion (AIC). The single lag models were better as compared to distributed lag models because of small (AIC) of the single lag models. For subsequent analyses, we selected the single lag with the most certain effect estimate, as determined by the AIC, separately for each cause of death.

\section{Results}

As shown in Table 1, a total of 62,515 deaths due to cardiovascular disease occurred among residents of Allegheny County, Pennsylvania during the period January 1, 1999 - December 30,2011 . Of these deaths, $34,945(55.9 \%)$ were attributed to IHD with $11,303(18.1 \%)$ to the IHD subgroup of AMI; 10,116 (16.2\%) to cerebrovascular disease; 4,358 (7.0\%) to heart failure; 2,256 (3.6\%) to PVD; 992 (1.6\%) to cardiac arrhythmias; and 9,848 (15.8\%) to other cardiovascular disease outcomes. Table 1 also shows the distribution of total and cause-specific deaths by demographics (age, gender, race, and education), place of death, and season. Approximately $60 \%$ of deaths were to individuals who were age 80 or older for most of the outcomes, except heart failure (75.2\%) and cardiac arrhythmia (41.1\%). Approximately half $(29,274$ or $46.8 \%)$ of the 62,515 CVD deaths from cardiovascular disease occurred at a hospital, 18,116 (29.0\%) at a nursing home, and 15,125 (24.2\%) occurred out of hospital/nursing home. Nearly all (95.0\%) of the out of hospital/nursing home deaths occurred at a residence. 
Table 2 presents the descriptive statistics for $\mathrm{PM}_{2.5}\left(\mu \mathrm{g} / \mathrm{m}^{3}\right), \mathrm{O}_{3}(\mathrm{ppb})$, and apparent mean temperature $\left({ }^{\circ} \mathrm{C}\right)$ averaged over the ZCTAs in Allegheny County during the period 1999-2011. Mean values were $13.92 \mu \mathrm{g} / \mathrm{m}^{3}$ for $\mathrm{PM}_{2.5}, 26.72$ for $\mathrm{O}_{3}(\mathrm{ppb})$, and $10.2(\mathrm{C})$ for apparent mean temperature during the entire study period. The pollutant levels for $\mathrm{PM}_{2.5}$ and $\mathrm{O}_{3}$ were higher during the warm period compared to the cold period. The correlation between pollutants and apparent mean temperature was low to moderate (Table 3). Figure 2 depicts monthly averages of pollutants, apparent mean temperature and cardiovascular deaths over the study period.

We estimated associations between daily modeled concentrations of $\mathrm{PM}_{2.5}$ at the ZIP code of residence and cause-specific CVD mortality for single day lags 0-5 (Table 4) and unconstrained distributed lag models (Table 5 and Figure 3). There were no statistically significant associations of $\mathrm{PM}_{2.5}$ with acute myocardial infarction, cerebrovascular disease, heart failure or cardiac arrhythmia deaths at any of the lags. For IHD and PVD mortality, although there were no statistically significant associations with $\mathrm{PM}_{2.5}$ for single lag days $0-4$ or for distributed lag days 04 days, there were significant associations at lag day 5 in both single and distributed lag models. For every $10 \mu \mathrm{g} / \mathrm{m}^{3}$ increase in $\mathrm{PM}_{2.5}$ at lag day 5, there was a 2.1\% (95\% CI, 0.2\%-4.1\%) increase in IHD mortality and a 7.6\% (95\% CI, 0.01\%-15.7\%) increase in PVD mortality, adjusting for $\mathrm{O}_{3}$ and apparent mean temperature (Table 4).

The observed associations between $\mathrm{PM}_{2.5}$ and cause-specific CVD mortality were further investigated for effect modification by age, gender, race, education, location at the time of death and season. Table 6 shows the percent change in risk and 95\% CI per $10 \mu \mathrm{g} / \mathrm{m}^{3}$ increase in $\mathrm{PM}_{2.5}$ for the selected lag by cause of death and subgroups. The risk of both overall cardiovascular and ischemic heart disease-specific mortality was significantly greater among those who died outside of a hospital or nursing home (4.9\%; 95\% CI: 1.3-8.6\%) than among those who died in a hospital (0.8\%; 95\% CI: $-2.1-3.7 \%)$ or nursing home $(1.3 \% ; 95 \%$ CI:-2.4-5.0\%), indicating a significant 
interaction of residence compared to other locations of death since $95 \%$ of deaths outside of a hospital or nursing home occurred at the residence.

Several observations were noted when we conducted subgroup analysis by age, race, education, gender, place of death and warmer or cold seasons. For total CVD mortality, we found higher risk estimates for males $(2.2 \%$; $95 \% \mathrm{CI}: 0.1-4.4 \%)$ compared to females $(0.3 \%$; $95 \%$ CI:1.6-2.3\%), for whites (1.7\%; 95\% CI: 0.1-3.2\%) compared to blacks (-2.0\%; 95\% CI: -6.8$1.7 \%)$, for those who died outside of a hospital or nursing home (3.8\%; 95\% CI: $0.9-6.9 \%)$ compared these dying in either hospital $(0.8 \%$; $95 \%$ CI: $-1.3-2.9 \%)$ or nursing homes $(-0.3 \%$; $95 \%$ CI: $-2.9-2.4 \%)$, and for the warmer months $(2.2 \%$; $95 \%$ CI: $0.2-4.2 \%)$ compared to the colder months (0.8\%; 95\% CI: $-1.4-3.0 \%)$.

\section{Discussion}

\section{Comparison with other County level Pm 2.5 Mass Concentration and Cardiovascular Mortality}

\section{Studies:}

A number of investigators have considered the associations of fine $\mathrm{PM}_{2.5}$ and cardiovascular mortality in other US counties/ metropolitan areas. (Fairley 1999) examined daily cardiovascular mortality and $\mathrm{PM}_{2.5}$ in Santa Clara County, California (1989-1996) using a time series approach. Significant effects were noted for $\mathrm{PM}_{2.5}$ and CVD deaths were noted in both in models with $\mathrm{PM}_{2.5}$ alone as well as with other pollutants (ozone, nitrate, $\mathrm{SO}_{2}$, and $\mathrm{CO}$ ). The overall risk estimate was 1.02 per $10 \mathrm{ug} / \mathrm{m}^{3} \mathrm{PM}_{2.5}$. Wilson et al. evaluated the influence of exposure error and effect modification by SES on the association of acute cardiovascular mortality and fine particulates in Phoenix, AZ for the period 1995-1997 (Wilson et al. 2007). They also considered ZIP code level mortality data and single lag days of 0-5 for three ZIP code areas surrounding the 
central city of Phoenix where there was one central monitoring site. It was acknowledged that the single monitor most likely introduced measurement error noting that the greatest and only significant effect was for the central Phoenix area compared to the Middle Ring area (1.15\% (2.8$20.9)$ and $2.9 \%(-2.9-11.4)$ respectively. This estimate was based on a six day moving average.

Ostro et al. considered fine particulate air pollution and mortality in nine California counties for the period (1999-2002) (Ostro et al. 2006). They showed an effect of CVD for $\mathrm{PM}_{2.5}$ $(1.06 \% ; 95 \% \mathrm{CI} ; 0.0-1.1)$, overall for all counties with a $0 / 1$ day lag and also showed a significant effect for out of hospital deaths for whites and women over age 65, and non HS graduates. Similar to our Pittsburgh study, Zhou reported increased risk of CVD death associated with $\mathrm{PM}_{2.5}$ in the warm months in Detroit but the opposite effect of an increased risk in cold months in Seattle (Zhou et al. 2011). In our study, higher effect estimates for older people were observed for IHD mortality.

Our study provides evidence of an association between short term exposure to ambient $\mathrm{PM}_{2}$. with IHD and PVD mortality at single lag day 5: (2.1\% (95\% CI, 0.2\%-4.1\%) and (7.6\%, 95\% CI, 0.05\%-15.7\%) respectively per $10 \mu \mathrm{g} / \mathrm{m} 3$ increase in $\mathrm{PM}_{2.5}$. as well as for distributed lag days 0-5, after adjusting for $\mathrm{O}_{3}$ and apparent mean temperature. This is consistent with other acute studies showing an increased risk of $\mathrm{PM}_{2.5}$ and IHD (Brook RD et al. 2010). Thurston et al. in a recent paper considering long term exposure to source related components of fine $\mathrm{PM}_{2.5}$ noted a five times increased risk of IHD mortality associated components of coal burning (IHD HR= 1.05, 95\% CI: 1.02-1.08) than for $\mathrm{PM}_{2.5}$ mass in general (Thurston et al. 2016). The fact that Pittsburgh still has among the greatest concentrations of coal-burning may in some way be associated. Future longer term studies with the inclusion of PM source related components should be carried out in cities with varying sources of $\mathrm{PM}_{2.5}$. 


\section{Strengths and Weaknesses of our Study:}

A major strength of our investigation is the use of refined exposure estimates by using a kriging interpolation method. The overall accuracy of the spatiotemporal kriging method was evaluated using a ten folds cross validation. Although the exposure measurement is not at the individual level, average ZIP code area exposure is at a much more resolute level than the use of a single monitor and represents a significant strength of this study.

We chose to use case crossover analysis for our study. One strength of case crossover is that in this design each case acts as his/her own control, thereby "adjusting" for age, race and gender and other subject characteristics that are do not vary or slowly vary over time. It also permits analysis of potential effect modification by considering categories such as race and gender. Another strength is that we examined the association of $\mathrm{PM}_{2.5}$ with subcategories of CVD.

The weakness is the lack of individual level data on access to care, specific indoor and outdoor individual level exposure estimates, and information on personal risk factors such as cigarette smoking, medication and specific health histories.

\section{Conclusion}

In summary, this study found that short term exposure to ambient $\mathrm{PM}_{2.5}$ air pollution was found to be significantly associated with IHD and PVD mortality in Allegheny County from 1999 to 2011 for distributed lag day 5 and single lag day 5. The risk of IHD mortality related to $\mathrm{PM}_{2.5}$ air pollution was also statistically significantly greater among individuals who died outside of a hospital or nursing home (nearly all at their residence) compared to individuals who died in a hospital or nursing home. This likely reflects a more accurate exposure to event phenomenon based on the ZIP code of their residence (out of hospital). 
The application of finer scale geographically resolved AP exposures made it possible to study acute effects of $\mathrm{PM}_{2.5}$ on CVD mortality in a large metropolitan area. Results of the study found that $\mathrm{PM}_{2.5}$ exposure was related to increased risk of death for several categories of CVD and demonstrate the continued presence of a dose response relationship of increased risk within this lower range of $\mathrm{PM}_{2.5}$. 


\section{References}

2010 Census. 2010. Http://www.Census.Gov/2010census/.

Arena VC, Mazumdar S, Zborowski JV, Talbott EO, He S, Chuang YH, et al. 2006. A retrospective investigation of pm10 in ambient air and cardiopulmonary hospital admissions in allegheny county, pennsylvania: 1995-2000. Journal of occupational and environmental medicine / American College of Occupational and Environmental Medicine 48:38-47.

Arnold J, Daroczi G, Werth B, Weitzner B, Kunst J, Auguie B, et al. 2016. Extra themes, scales and geoms for 'ggplot2'.

Baquero O. 2016. North symbols and scale bars for maps created with 'ggplot2' or 'ggmap'.

Becker R, Wilks A. 2016. Original s code $r$ version by ray brownrigg. Enhancements by thomas $p$ minka and alex deckmyn

Bivand R, Keitt T, Rowlingson B, Pebesma E, Sumner M, Hijmans R, et al. 2016. Bindings for the geospatial data abstraction library.

Brook RD, Rajagopalan S, Pope CA 3rd, Brook JR, Bhatnagar A, Diez-Roux AV, et al. 2010. Particulate matter air pollution and cardiovascular disease: An update to the scientific statement from the american heart association. Circulation 121:2331-2378.

Chock DP, Winkler SL, Chen C. 2000. A study of the association between daily mortality and ambient air pollutant concentrations in pittsburgh, pennsylvania. Journal of the Air \& Waste Management Association (1995) 50:1481-1500.

Cressie N, Wikle CK. 2011. Statistics for spatio-temporal data. John Wiley \& Sons Chapter 6.2.

De Iaco S, Myers DE, Posa D. 2002. Space-time variograms and a functional form for total air pollution measurements. Computational Statistics \& Data Analysis 41:311-328.

Fairley D. 1999. Daily mortality and air pollution in santa clara county, california: 1989-1996. Environmental health perspectives 107:637-641.

Franklin M, Zeka A, Schwartz J. 2007. Association between pm2.5 and all-cause and specificcause mortality in 27 us communities. Journal of exposure science \& environmental epidemiology 17:279-287.

Franklin M, Koutrakis P, Schwartz P. 2008. The role of particle composition on the association between pm2.5 and mortality. Epidemiology (Cambridge, Mass) 19:680-689.

Haley VB, Talbot TO, Felton HD. 2009. Surveillance of the short-term impact of fine particle air pollution on cardiovascular disease hospitalizations in new york state. Environmental health : a global access science source 8:42. 
Ito K, Mathes R, Ross Z, Nadas A, Thurston G, Matte T. 2011. Fine particulate matter constituents associated with cardiovascular hospitalizations and mortality in new york city. Environmental health perspectives 119:467-473.

Kahle D, Wickham H. 2013. Ggmap: Spatial visualization with ggplot2. The R Journal 5:144-161.

Maclure M. 1991. The case-crossover design: A method for studying transient effects on the risk of acute events. American journal of epidemiology 133:144-153.

Mazumdar S, Sussman N. 1983. Relationships of air pollution to health: Results from the pittsburgh study. Archives of environmental health 38:17-24.

Minasny B, McBratney AB. 2005. The matérn function as a general model for soil variograms. Geoderma 128:192-207.

Ostro B, Broadwin R, Green S, Feng WY, Lipsett M. 2006. Fine particulate air pollution and mortality in nine california counties: Results from calfine. Environmental health perspectives 114:29-33.

Samoli E, Stafoggia M, Rodopoulou S, Ostro B, Alessandrini E, Basagana X, et al. 2014. Which specific causes of death are associated with short term exposure to fine and coarse particles in southern europe? Results from the med-particles project. Environment international 67:54-61.

Shah AS, Langrish JP, Nair H, McAllister DA, Hunter AL, Donaldson K, et al. 2013. Global association of air pollution and heart failure: A systematic review and meta-analysis. Lancet 382:1039-1048.

Shang Y, Sun Z, Cao J, Wang X, Zhong L, Bi X, et al. 2013. Systematic review of chinese studies of short-term exposure to air pollution and daily mortality. Environment international 54:100-111.

Steadman RG. 1979. The assessment of sultriness. Part i: A temperature-humidity index based on human physiology and clothing science. J Appl Meteor 18:861-873.

Thurston GD, Burnett RT, Turner MC, Shi Y, Krewski D, Lall R, et al. 2016. Ischemic heart disease mortality and long-term exposure to source-related components of u.S. Fine particle air pollution. Environmental health perspectives 124:785-794.

Tunno BJ, Michanowicz DR, Shmool JL, Kinnee E, Cambal L, Tripathy S, et al. 2016. Spatial variation in inversion-focused vs 24-h integrated samples of pm2.5 and black carbon across pittsburgh, pa. Journal of exposure science \& environmental epidemiology 26:365-376.

US Census-ZCTA. Https://www.Census.Gov/geo/reference/zctas.Html.

Wickham H. 2009. Ggplot2: Elegant graphics for data analysis. Springer-Verlag New York.

Wickham H. 2011. The split-apply-combine strategy for data analysis. Journal of Statistical Software 40:1-29. 
Wilson WE, Mar TF, Koenig JQ. 2007. Influence of exposure error and effect modification by socioeconomic status on the association of acute cardiovascular mortality with particulate matter in phoenix. Journal of exposure science \& environmental epidemiology 17 Suppl 2:S11-19.

Zhou J, Ito K, Lall R, Lippmann M, Thurston G. 2011. Time-series analysis of mortality effects of fine particulate matter components in detroit and seattle. Environmental health perspectives 119:461-466. 
Table 1. Cardiovascular Disease Deaths (ICD-10 I00-I99) by Type and Characteristics among Allegheny County, Pennsylvania residents, 1999-2011

\begin{tabular}{|c|c|c|c|c|c|c|c|c|c|c|c|c|c|c|}
\hline \multirow[t]{2}{*}{ ICD-10 Codes } & \multicolumn{2}{|c|}{$\begin{array}{c}\text { Cardiovascular } \\
\text { Disease } \\
\text { I00 - I99 } \\
\end{array}$} & \multicolumn{2}{|c|}{$\begin{array}{c}\text { Ischemic } \\
\text { Heart Disease } \\
\text { I20 - I25 } \\
\end{array}$} & \multicolumn{2}{|c|}{$\begin{array}{c}\text { Acute } \\
\text { Myocardial } \\
\text { Infarction* } \\
\text { I21 }\end{array}$} & \multicolumn{2}{|c|}{$\begin{array}{c}\text { Cerebrovascular } \\
\text { Disease } \\
\text { I60 - I69 } \\
\end{array}$} & \multicolumn{2}{|c|}{$\begin{array}{c}\text { Heart } \\
\text { Failure } \\
\text { I50 } \\
\end{array}$} & \multicolumn{2}{|c|}{$\begin{array}{c}\text { Peripheral } \\
\text { Vascular } \\
\text { disease } \\
\text { I70 - I79 } \\
\end{array}$} & \multicolumn{2}{|c|}{$\begin{array}{c}\text { Cardiac } \\
\text { Arrhythmia } \\
\text { I47-I49 } \\
\end{array}$} \\
\hline & $\mathbf{N}$ & $\%$ & $\mathbf{N}$ & $\%$ & $\mathbf{N}$ & $\%$ & $\mathbf{N}$ & $\%$ & $\mathbf{N}$ & $\%$ & $\mathbf{N}$ & $\%$ & $\mathbf{N}$ & $\%$ \\
\hline Total & 62515 & 100.0 & 34945 & 100.0 & 11303 & 100.0 & 10116 & 100.0 & 4358 & 100.0 & 2256 & 100.0 & 992 & 100.0 \\
\hline \multicolumn{15}{|l|}{ Age (years) } \\
\hline$<80$ & 25545 & 40.9 & 14920 & 42.7 & 4919 & 43.5 & 3622 & 35.8 & 1079 & 24.8 & 929 & 41.2 & 584 & 58.9 \\
\hline$\geq 80$ & 36966 & 59.1 & 20022 & 57.3 & 6382 & 56.5 & 6493 & 64.2 & 3279 & 75.2 & 1327 & 58.8 & 408 & 41.1 \\
\hline \multicolumn{15}{|l|}{ Gender } \\
\hline Male & 28096 & 44.9 & 16880 & 48.3 & 5132 & 45.4 & 3794 & 37.5 & 1699 & 39.0 & 942 & 41.8 & 384 & 38.7 \\
\hline Female & 34419 & 55.1 & 18065 & 51.7 & 6171 & 54.6 & 6322 & 62.5 & 2659 & 61.0 & 1314 & 58.2 & 608 & 61.3 \\
\hline \multicolumn{15}{|l|}{ Race } \\
\hline White & 55739 & 89.2 & 31499 & 90.1 & 10241 & 90.6 & 8952 & 88.5 & 3967 & 91.0 & 2039 & 90.4 & 815 & 82.2 \\
\hline Black & 6571 & 10.5 & 3332 & 9.5 & 1032 & 9.1 & 1126 & 11.1 & 377 & 8.7 & 210 & 9.3 & 174 & 17.5 \\
\hline Other & 173 & 0.3 & 96 & 0.3 & 27 & 0.2 & 36 & 0.4 & 12 & 0.3 & 5 & 0.2 & 2 & 0.2 \\
\hline \multicolumn{15}{|l|}{$\begin{array}{l}\text { Education } \\
\text { (years) }\end{array}$} \\
\hline$<12$ & 15663 & 25.1 & 8790 & 25.2 & 2772 & 24.5 & 2407 & 23.8 & 1318 & 30.2 & 62 & 2.8 & 211 & 21.3 \\
\hline 12 & 31760 & 50.8 & 17820 & 51.0 & 5921 & 52.4 & 5187 & 51.3 & 2064 & 47.4 & 612 & 27.1 & 508 & 51.2 \\
\hline$>12$ & 13597 & 21.8 & 7465 & 21.4 & 2368 & 21.0 & 2319 & 22.9 & 864 & 19.8 & 1135 & 50.3 & 257 & 25.9 \\
\hline \multicolumn{15}{|l|}{$\begin{array}{l}\text { Location of } \\
\text { death }\end{array}$} \\
\hline Hospital & 29274 & 46.8 & 15105 & 43.2 & 6165 & 54.5 & 5318 & 52.6 & 1848 & 42.4 & 1383 & 61.3 & 723 & 72.9 \\
\hline Nursing home & 18116 & 29.0 & 9522 & 27.3 & 2516 & 22.3 & 3826 & 37.8 & 1867 & 42.8 & 570 & 25.3 & 116 & 11.7 \\
\hline$* *$ Other & 15125 & 24.2 & 10318 & 29.5 & 2622 & 23.2 & 972 & 9.6 & 643 & 14.8 & 303 & 13.4 & 153 & 15.4 \\
\hline \multicolumn{15}{|l|}{ Season } \\
\hline Cold & 33350 & 53.4 & 18659 & 53.4 & 6056 & 53.6 & 5439 & 53.8 & 2319 & 53.2 & 1218 & 54.0 & 551 & 55.5 \\
\hline Warm & 29165 & 46.7 & 16286 & 46.6 & 5247 & 46.4 & 4677 & 46.2 & 2039 & 46.8 & 1038 & 46.0 & 441 & 44.5 \\
\hline
\end{tabular}

*Mortality due to Acute Myocardial Infraction is a sub-category of Ischemic Heart Disease

** Outside of hospital or nursing home ( $95 \%$ of these deaths occurred at residence) 
Table 2. Descriptive statistics for $\mathbf{P M}_{2.5}$, ozone, and apparent mean temperature in Allegheny County, Pennsylvania, 1999-2011

\begin{tabular}{|c|c|c|c|c|c|c|c|c|}
\hline \multicolumn{2}{|c|}{ Air Pollutants } & Mean & SD & Median & Q1 & Q3 & Min & $\operatorname{Max}$ \\
\hline \multirow[t]{3}{*}{$\mathbf{P M}_{2.5}\left(\mu \mathrm{g} / \mathrm{m}^{3}\right)$} & Whole Year & 13.92 & 7.63 & 12.28 & 8.42 & 17.45 & 0.84 & 64.46 \\
\hline & Warm* & 15.79 & 8.68 & 13.81 & 9.29 & 20.09 & 1.17 & 64.46 \\
\hline & Cold* & 12.03 & 5.84 & 11.04 & 7.75 & 15.19 & 0.84 & 49.83 \\
\hline \multirow[t]{3}{*}{$\mathbf{O}_{3}(\mathbf{p p b})$} & Whole Year & 26.72 & 9.95 & 26.50 & 19.24 & 33.93 & 0.05 & 83.30 \\
\hline & Warm* & 32.62 & 8.31 & 32.78 & 27.01 & 38.07 & 3.69 & 83.30 \\
\hline & Cold* & 20.81 & 7.70 & 20.28 & 15.35 & 25.79 & 0.05 & 65.92 \\
\hline Apparent Mean & Whole Year & 10.19 & 11.04 & 10.33 & 0.45 & 19.77 & -12.57 & 35.37 \\
\hline \multirow[t]{2}{*}{ Temperature $\left({ }^{\circ} \mathbf{C}\right)$} & Warm period* & 18.66 & 7.10 & 19.63 & 14.02 & 24.09 & -4.32 & 35.37 \\
\hline & Cold period* & 1.68 & 6.99 & 0.63 & -3.60 & 6.41 & -12.57 & 25.65 \\
\hline
\end{tabular}

* Warm period is from April to September, cold period is from October to March 
Table 3. Spearman correlation between pollutants and apparent mean temperature, Allegheny County, Pennsylvania (January $1^{\text {st }} 1999$ - December $\left.31^{\text {st }} 2011\right)(\mathrm{N}=460556$. Empirical significance levels $(\mathrm{P})$ were all $<0.0001$.

\begin{tabular}{rccc} 
& $\mathbf{P M}_{2.5}\left(\boldsymbol{\mu g} / \mathbf{m}^{\mathbf{3}}\right)$ & $\mathbf{O}_{\mathbf{3}}(\mathbf{p p b})$ & $\begin{array}{c}\text { Apparent mean } \\
\text { temperature }\left({ }^{\circ} \mathbf{C}\right)\end{array}$ \\
\cline { 2 - 4 } $\mathbf{P M}_{\mathbf{2 . 5}}\left(\boldsymbol{\mu g} / \mathbf{m}^{\mathbf{3}}\right)$ & 1.000 & & \\
$\mathbf{O}_{\mathbf{3}}(\mathbf{p p b})$ & 0.186 & 1.000 & \\
Apparent mean & 0.393 & 0.536 & 1.000
\end{tabular}


Table 4. Percent change in risk (and $95 \%$ CI) of mortality per $10 \mu \mathrm{g} / \mathrm{m3}$ increase in $\mathrm{PM}_{2.5}$, by cause of CVD death, adjusted for $\mathrm{O3}$ and apparent mean temperature, Allegheny County, Pennsylvania residents, 1999-2011: Single day lag models.

\begin{tabular}{|c|c|c|c|c|c|c|c|c|c|c|c|c|c|c|c|c|c|c|c|}
\hline \multirow{4}{*}{$\begin{array}{l}\quad \text { Outcome / I } \\
\text { Cardiovascular } \\
\text { Disease }\end{array}$} & \multirow{4}{*}{$\begin{array}{r}\% \\
\text { Change } \\
10 \text { Codes } \\
\text { I00- I99 }\end{array}$} & \multicolumn{3}{|c|}{ Lag 0} & \multicolumn{3}{|c|}{ Lag 1} & \multicolumn{3}{|c|}{ Lag 2} & \multicolumn{3}{|c|}{ Lag 3} & \multicolumn{3}{|c|}{ Lag 4} & \multicolumn{3}{|c|}{ Lag 5} \\
\hline & & \multirow[t]{2}{*}{$\%$} & \multicolumn{2}{|c|}{$95 \% \mathrm{CI}$} & \multirow[t]{2}{*}{$\%$} & \multicolumn{2}{|c|}{$95 \% \mathrm{CI}$} & \multirow[t]{2}{*}{$\%$} & \multicolumn{2}{|c|}{$95 \% \mathrm{CI}$} & \multirow[t]{2}{*}{$\%$} & \multicolumn{2}{|c|}{$95 \%$ CI } & \multirow[t]{2}{*}{$\%$} & \multicolumn{2}{|c|}{$95 \%$ CI } & \multirow[t]{2}{*}{$\%$} & \multicolumn{2}{|c|}{$95 \%$ CI } \\
\hline & & & $\mathbf{L}$ & $\mathbf{U}$ & & $\mathbf{L}$ & $\mathbf{U}$ & & $\mathbf{L}$ & $\mathbf{U}$ & & $\mathbf{L}$ & $\mathbf{U}$ & & $\mathbf{L}$ & $\mathbf{U}$ & & $\mathbf{L}$ & $\mathbf{U}$ \\
\hline & & 0.7 & -0.7 & 2.1 & 1 & -0.4 & 2.4 & -0.2 & -1.6 & 1.2 & 0.1 & -1.3 & 1.6 & 0.3 & -1.1 & 1.7 & 1.2 & -0.2 & 2.6 \\
\hline Ischemic Heart & I20- I 25 & 0.1 & -1.8 & 2 & 0.8 & -1.1 & 2.8 & -0.2 & -2.1 & 1.7 & -0.2 & -2 & 1.8 & 0.7 & -1.2 & 2.6 & 2.1 & 0.2 & 4.1 \\
\hline $\begin{array}{l}\text { Acute Myocardial } \\
\text { Infraction }\end{array}$ & I21 & 0.1 & -3.1 & 3.4 & 0.1 & -3.1 & 3.5 & -1.9 & -5.2 & 1.4 & -1.2 & -4.4 & 2.2 & -2 & -5.3 & 1.3 & -0.2 & -3.5 & 3.2 \\
\hline $\begin{array}{l}\text { Cerebrovascular } \\
\text { Disease }\end{array}$ & I60- I69 & 3.4 & -0.1 & 7.1 & 1.9 & -1.7 & 5.5 & 0.8 & -2.7 & 4.4 & -1.2 & -4.7 & 2.4 & -2 & .5 .4 & 1.5 & -2.5 & -5.9 & 1.1 \\
\hline Heart Failure & I50 & -0.2 & -5.5 & 5.3 & -1.2 & -6.5 & 4.4 & -3.4 & -8.5 & 2.1 & 2.8 & -2.6 & 8.6 & 1.8 & -3.6 & 7.4 & 0.7 & -4.6 & 6.3 \\
\hline $\begin{array}{l}\text { Peripheral } \\
\text { Vascular Disease }\end{array}$ & I70- I79 & -1.8 & -8.8 & 5.8 & 2.8 & -4.4 & 10.4 & 5.1 & -2.4 & 13.1 & 7.9 & 0.2 & 16.2 & 4.8 & -2.7 & 12.9 & 7.6 & 0.1 & 15.7 \\
\hline $\begin{array}{l}\text { Cardiac } \\
\text { arrhythmia }\end{array}$ & I47- I49 & -2 & -12.6 & 9.9 & -11.8 & -21.6 & -0.8 & -2.1 & -12.7 & 9.9 & 6.8 & -5.2 & 20.3 & -8 & -18.3 & 3.5 & 6.3 & -5 & 19 \\
\hline
\end{tabular}


Table 5. Percent change in risk (and $95 \% \mathrm{CI}$ ) of mortality per $10 \mu \mathrm{g} / \mathrm{m3}$ increase in $\mathrm{PM}_{2.5}$, by cause of CVD death, adjusted for $\mathrm{O3}$

and apparent mean temperature, Allegheny County, Pennsylvania residents, 1999-2011: Distributed lag model.

\begin{tabular}{|c|c|c|c|c|c|c|c|c|c|c|c|c|c|c|c|c|c|c|c|}
\hline \multirow{4}{*}{$\begin{array}{l}\quad \text { Outcome / I } \\
\text { Cardiovascular } \\
\text { Disease }\end{array}$} & \multirow{4}{*}{$\begin{array}{r}\% \\
\text { Change } \\
\text { ICD-10 Codes } \\
\text { I00- I99 }\end{array}$} & \multicolumn{3}{|c|}{ Lag 0} & \multicolumn{3}{|c|}{ Lag 1} & \multicolumn{3}{|c|}{ Lag 2} & \multicolumn{3}{|c|}{ Lag 3} & \multicolumn{3}{|c|}{ Lag 4} & \multicolumn{3}{|c|}{ Lag 5} \\
\hline & & \multirow[t]{2}{*}{$\%$} & \multicolumn{2}{|c|}{$95 \% \mathrm{CI}$} & \multirow[t]{2}{*}{$\%$} & \multicolumn{2}{|c|}{$95 \% \mathrm{CI}$} & \multirow[t]{2}{*}{$\%$} & \multicolumn{2}{|c|}{$95 \% \mathrm{CI}$} & \multirow[t]{2}{*}{$\%$} & \multicolumn{2}{|c|}{$95 \%$ CI } & \multirow[t]{2}{*}{$\%$} & \multicolumn{2}{|c|}{$95 \%$ CI } & \multirow[t]{2}{*}{$\%$} & \multicolumn{2}{|c|}{$95 \%$ CI } \\
\hline & & & $\mathbf{L}$ & $\mathbf{U}$ & & $\mathbf{L}$ & $\mathbf{U}$ & & $\mathbf{L}$ & $\mathbf{U}$ & & $\mathbf{L}$ & $\mathbf{U}$ & & $\mathbf{L}$ & $\mathbf{U}$ & & $\mathbf{L}$ & $\mathbf{U}$ \\
\hline & & -0.4 & -2.1 & 1.3 & 0.3 & -1.8 & 2.5 & -1.1 & -3.3 & 1.1 & 0.8 & -1.4 & 3.1 & -1.6 & -3.7 & 0.6 & 2.3 & 0.4 & 4.1 \\
\hline Ischemic Heart & I20- I 25 & -1.4 & -3.7 & 0.9 & -0.1 & -2.9 & 2.8 & -0.1 & -3.0 & 2.9 & -0.2 & -3.1 & 2.9 & -1.5 & -4.3 & 1.5 & 3.3 & 0.9 & 5.9 \\
\hline $\begin{array}{l}\text { Acute Myocardial } \\
\text { Infraction }\end{array}$ & I21 & -2.0 & -5.9 & 2.0 & 1.0 & -3.9 & 6.2 & -2.3 & -7.3 & 3.0 & 0.8 & -4.3 & 6.2 & -3.1 & -8.0 & 2.0 & 1.8 & -2.4 & 6.3 \\
\hline $\begin{array}{l}\text { Cerebrovascular } \\
\text { Disease }\end{array}$ & I60- I69 & 2.7 & -1.6 & 7.3 & -2.6 & -7.7 & 2.8 & 1.9 & -3.6 & 7.8 & -1.6 & -7.0 & 4.1 & 1.5 & -3.9 & 7.3 & -1.8 & -6.2 & 2.8 \\
\hline Heart Failure & I50 & -0.3 & -6.7 & 6.6 & 2.3 & -5.8 & 11.2 & -6.2 & -13.9 & 2.1 & 5.7 & -3.0 & 15.3 & -3.2 & -11.1 & 5.5 & 0.8 & -6.0 & 8.2 \\
\hline $\begin{array}{l}\text { Peripheral } \\
\text { Vascular Disease }\end{array}$ & I70- I79 & -3.1 & -11.5 & 6.0 & 4.2 & -6.5 & 16.2 & -3.3 & -13.9 & 8.6 & 7.6 & -4.3 & 20.9 & -5.9 & -16.2 & 5.7 & 8.3 & -1.5 & 19.0 \\
\hline $\begin{array}{l}\text { Cardiac } \\
\text { Arrhythmia }\end{array}$ & I47- I49 & 5.7 & -8.3 & 21.9 & -14.7 & -28.5 & 1.7 & 0.4 & -16.2 & 20.3 & 15.8 & -3.9 & 39.5 & -20.0 & -33.5 & -3.8 & 15.2 & -4.0 & 33.0 \\
\hline
\end{tabular}


Table 6. Percent change in risk (and $95 \%$ CI) of mortality per $10 \mu \mathrm{g} / \mathrm{m}^{3} \mathrm{PM}_{2.5}$ for selected single day lags, by cause of CVD death and subgroup, adjusted for $\mathrm{O}_{3}$ and apparent mean temperature, Allegheny County, Pennsylvania residents, $1999-2011$.

\begin{tabular}{|c|c|c|c|c|c|c|c|c|c|c|c|c|c|c|c|c|c|c|c|c|c|}
\hline \multirow{3}{*}{$\begin{array}{r}\text { ICD-10 Codes } \\
\% \text { Inc. }\end{array}$} & \multicolumn{3}{|c|}{$\begin{array}{c}\text { Cardiovascular } \\
\text { Disease (Lag5) } \\
\text { I00 - I99 } \\
\end{array}$} & \multicolumn{3}{|c|}{$\begin{array}{c}\text { Ischemic Heart } \\
\text { Disease (Lag5) } \\
\text { I20 - I25 }\end{array}$} & \multicolumn{3}{|c|}{$\begin{array}{c}\text { Acute Myocardial } \\
\text { Infarction (Lag1) } \\
\text { I21 } \\
\end{array}$} & \multicolumn{3}{|c|}{$\begin{array}{c}\text { Cerebrovascular } \\
\text { Disease (Lag2) } \\
\text { I60 - I69 }\end{array}$} & \multicolumn{3}{|c|}{$\begin{array}{c}\text { Heart Failure } \\
\text { (Lag2) } \\
\text { I50 }\end{array}$} & \multicolumn{3}{|c|}{$\begin{array}{c}\text { Peripheral Vascular } \\
\text { Disease (Lag5) } \\
\text { I70 - I79 }\end{array}$} & \multicolumn{3}{|c|}{$\begin{array}{c}\text { Cardiac } \\
\text { Arrhythmia } \\
\text { (Lag1) } \\
\text { I47-I49 }\end{array}$} \\
\hline & \multirow[t]{2}{*}{$\%$} & \multicolumn{2}{|c|}{$95 \%$ CI } & \multirow[t]{2}{*}{$\%$} & \multicolumn{2}{|c|}{$95 \%$ CI } & \multirow[t]{2}{*}{$\%$} & \multicolumn{2}{|c|}{$95 \% \mathrm{CI}$} & \multirow[t]{2}{*}{$\%$} & \multicolumn{2}{|c|}{$95 \% \mathrm{CI}$} & \multirow[t]{2}{*}{$\%$} & \multicolumn{2}{|c|}{$95 \% \mathrm{CI}$} & \multirow[t]{2}{*}{$\%$} & \multicolumn{2}{|c|}{$95 \%$ CI } & \multirow[t]{2}{*}{$\%$} & \multicolumn{2}{|c|}{$95 \% \mathrm{CI}$} \\
\hline & & $\mathbf{L}$ & $\mathbf{U}$ & & $\mathbf{L}$ & $\mathbf{U}$ & & $\mathbf{L}$ & $\mathbf{U}$ & & $\mathbf{L}$ & $\mathbf{U}$ & & $\mathbf{L}$ & $\mathbf{U}$ & & $\mathbf{L}$ & $\mathbf{U}$ & & $\mathbf{L}$ & $\mathbf{U}$ \\
\hline $\begin{array}{l}\text { Age (years) } \\
\quad<80 \\
\geq 80\end{array}$ & $\begin{array}{l}1.4 \\
1.0\end{array}$ & $\begin{array}{l}-0.8 \\
-0.8\end{array}$ & $\begin{array}{l}3.6 \\
2.9\end{array}$ & $\begin{array}{l}1.4 \\
2.6\end{array}$ & $\begin{array}{r}-1.5 \\
\mathbf{0 . 1}\end{array}$ & $\begin{array}{l}4.4 \\
\mathbf{5 . 2}\end{array}$ & $\begin{array}{l}0.0 \\
0.4\end{array}$ & $\begin{array}{l}-4.8 \\
-4.0\end{array}$ & $\begin{array}{l}5.1 \\
4.9\end{array}$ & $\begin{array}{r}-0.8 \\
1.7\end{array}$ & $\begin{array}{l}-6.5 \\
-2.7\end{array}$ & $\begin{array}{l}5.2 \\
6.3\end{array}$ & $\begin{array}{l}-2.7 \\
-3.6\end{array}$ & $\begin{array}{r}-12.9 \\
-9.5\end{array}$ & $\begin{array}{l}8.7 \\
2.7\end{array}$ & $\begin{array}{l}8.6 \\
6.6\end{array}$ & $\begin{array}{l}-2.8 \\
-3.3\end{array}$ & $\begin{array}{l}21.4 \\
17.4\end{array}$ & $\begin{array}{r}-9.3 \\
-15.0\end{array}$ & $\begin{array}{l}-22.2 \\
-29.3\end{array}$ & $\begin{array}{l}5.7 \\
2.2\end{array}$ \\
\hline $\begin{array}{l}\text { Gender } \\
\text { Male } \\
\text { Female }\end{array}$ & $\begin{array}{l}2.2 \\
0.3\end{array}$ & $\begin{array}{r}\mathbf{0 . 1} \\
-1.6\end{array}$ & $\begin{array}{l}4.4 \\
2.3\end{array}$ & $\begin{array}{l}2.7 \\
1.6\end{array}$ & $\begin{array}{l}-0.1 \\
-1.1\end{array}$ & $\begin{array}{l}5.5 \\
4.3\end{array}$ & $\begin{array}{r}2.4 \\
-1.7\end{array}$ & $\begin{array}{l}-2.5 \\
-6.0\end{array}$ & $\begin{array}{l}7.5 \\
2.8\end{array}$ & $\begin{array}{l}0.7 \\
0.8\end{array}$ & $\begin{array}{l}-4.9 \\
-3.6\end{array}$ & $\begin{array}{l}6.7 \\
5.5\end{array}$ & $\begin{array}{l}-5.1 \\
-2.2\end{array}$ & $\begin{array}{r}-13.1 \\
-8.9\end{array}$ & $\begin{array}{l}3.6 \\
4.9\end{array}$ & $\begin{array}{r}13.7 \\
3.7\end{array}$ & $\begin{array}{r}1.5 \\
-5.8\end{array}$ & $\begin{array}{l}27.3 \\
14.1\end{array}$ & $\begin{array}{r}-19.4 \\
-6.1\end{array}$ & $\begin{array}{l}-33.5 \\
-19.1\end{array}$ & $\begin{array}{r}-2.3 \\
9.0\end{array}$ \\
\hline $\begin{array}{l}\text { Race } \\
\text { White } \\
\text { Black } \\
\text { Others }\end{array}$ & $\begin{array}{r}\mathbf{1 . 7} \\
-2.0 \\
-1.0\end{array}$ & $\begin{array}{r}\mathbf{0 . 1} \\
-6.8 \\
-24.6\end{array}$ & $\begin{array}{r}3.2 \\
1.7 \\
29.9\end{array}$ & $\begin{array}{l}2.3 \\
1.1 \\
-23\end{array}$ & $\begin{array}{r}\mathbf{0 . 2} \\
-4.9 \\
-49\end{array}$ & $\begin{array}{r}4.3 \\
7.4 \\
16.2\end{array}$ & $\begin{array}{r}0.8 \\
-6.3 \\
10.6\end{array}$ & $\begin{array}{r}-2.6 \\
-15.9 \\
-45.9\end{array}$ & $\begin{array}{r}4.4 \\
4.4 \\
125.8\end{array}$ & $\begin{array}{r}1.2 \\
0.0 \\
-48.7\end{array}$ & $\begin{array}{r}-2.6 \\
-10.0 \\
-75.4\end{array}$ & $\begin{array}{r}5.1 \\
11.0 \\
6.7\end{array}$ & $\begin{array}{r}-3.4 \\
-2.2 \\
-97.1\end{array}$ & $\begin{array}{r}-8.8 \\
-18.5 \\
-99.9\end{array}$ & $\begin{array}{r}2.3 \\
17.3 \\
4.9\end{array}$ & $\begin{array}{r}6.2 \\
26.9 \\
-32.5\end{array}$ & $\begin{array}{r}-1.7 \\
-0.6 \\
-83.9\end{array}$ & $\begin{array}{r}14.6 \\
61.9 \\
182.3\end{array}$ & $\begin{array}{r}-10 \\
-23.6 \\
-\end{array}$ & $\begin{array}{r}-20.7 \\
-43.9 \\
-\end{array}$ & $\begin{array}{r}2.3 \\
4.2 \\
-\end{array}$ \\
\hline $\begin{array}{l}\text { Education (years) } \\
\text { <12 years } \\
12 \text { year }(\mathrm{HS}) \\
>12 \text { years }\end{array}$ & $\begin{array}{l}1.5 \\
0.7 \\
1.5\end{array}$ & $\begin{array}{l}-1.3 \\
-1.2 \\
-1.6\end{array}$ & $\begin{array}{l}4.4 \\
2.8 \\
4.7\end{array}$ & $\begin{array}{l}0.7 \\
2.7 \\
1.9\end{array}$ & $\begin{array}{r}-3.0 \\
0.0 \\
-2.2\end{array}$ & $\begin{array}{l}4.6 \\
5.5 \\
6.2\end{array}$ & $\begin{array}{r}-5.1 \\
1.1 \\
3.9\end{array}$ & $\begin{array}{r}-11.3 \\
-3.4 \\
-3.4\end{array}$ & $\begin{array}{r}1.4 \\
5.8 \\
11.7\end{array}$ & $\begin{array}{r}-0.9 \\
0.8 \\
1.9\end{array}$ & $\begin{array}{l}-7.7 \\
-4.1 \\
-5.4\end{array}$ & $\begin{array}{l}6.5 \\
5.9 \\
9.8\end{array}$ & $\begin{array}{r}-4.1 \\
-5.6 \\
5.8\end{array}$ & $\begin{array}{r}-13.1 \\
-12.8 \\
-6.5\end{array}$ & $\begin{array}{r}6.0 \\
2.3 \\
19.6\end{array}$ & $\begin{array}{r}-1.1 \\
9.1 \\
14.1\end{array}$ & $\begin{array}{r}-14.2 \\
-1.5 \\
-3.3\end{array}$ & $\begin{array}{l}14.0 \\
20.8 \\
34.5\end{array}$ & $\begin{array}{r}-9.5 \\
-14.5 \\
-8.0\end{array}$ & $\begin{array}{l}-29.3 \\
-27.6 \\
-27.3\end{array}$ & $\begin{array}{r}15.8 \\
1.0 \\
16.3\end{array}$ \\
\hline $\begin{array}{l}\text { Location of death } \\
\text { Hospital } \\
\text { Nursing home } \\
* * \text { Other }\end{array}$ & $\begin{array}{r}0.8 \\
-0.3 \\
\mathbf{3 . 8}\end{array}$ & $\begin{array}{r}-1.3 \\
-2.9 \\
\mathbf{0 . 9}\end{array}$ & $\begin{array}{l}2.9 \\
2.4 \\
6.9\end{array}$ & $\begin{array}{l}0.8 \\
1.3 \\
4.9\end{array}$ & $\begin{array}{r}-2.1 \\
-2.4 \\
\mathbf{1 . 3}\end{array}$ & $\begin{array}{r}3.7 \\
5.0 \\
8.6^{*}\end{array}$ & $\begin{array}{r}0.6 \\
-6.0 \\
4.7\end{array}$ & $\begin{array}{r}-3.7 \\
-12.5 \\
-2.1\end{array}$ & $\begin{array}{r}5.2 \\
1.1 \\
12.0\end{array}$ & $\begin{array}{r}-1.4 \\
5.0 \\
-2.7\end{array}$ & $\begin{array}{r}-6.1 \\
-0.9 \\
-13.1\end{array}$ & $\begin{array}{r}3.5 \\
11.3 \\
8.9\end{array}$ & $\begin{array}{r}-8.5 \\
3.1 \\
-8.3\end{array}$ & $\begin{array}{r}-16 \\
-5.0 \\
-20.8\end{array}$ & $\begin{array}{r}-0.3 \\
11.8 \\
6.2\end{array}$ & $\begin{array}{r}11.6 \\
3.2 \\
-2.4\end{array}$ & $\begin{array}{r}1.7 \\
-10.8 \\
-20.5\end{array}$ & $\begin{array}{l}22.4 \\
19.4 \\
19.8\end{array}$ & $\begin{array}{r}-11.2 \\
-4.6 \\
-20.5\end{array}$ & $\begin{array}{l}-22.5 \\
-32.4 \\
-41.9\end{array}$ & $\begin{array}{r}1.8 \\
34.5 \\
8.7\end{array}$ \\
\hline $\begin{array}{l}\text { Season } \\
\text { Cold } \\
\text { Warm }\end{array}$ & $\begin{array}{l}0.8 \\
2.2\end{array}$ & $\begin{array}{r}-1.4 \\
\mathbf{0 . 2}\end{array}$ & $\begin{array}{l}3.0 \\
4.2\end{array}$ & $\begin{array}{l}0.8 \\
3.5\end{array}$ & $\begin{array}{r}-2.3 \\
\mathbf{0 . 7}\end{array}$ & $\begin{array}{l}3.9 \\
6.5\end{array}$ & $\begin{array}{r}0.0 \\
-1.0\end{array}$ & $\begin{array}{l}-5.2 \\
-5.7\end{array}$ & $\begin{array}{l}5.5 \\
3.9\end{array}$ & $\begin{array}{r}-0.1 \\
1.2\end{array}$ & $\begin{array}{l}-5.7 \\
-4.0\end{array}$ & $\begin{array}{l}5.7 \\
6.6\end{array}$ & $\begin{array}{l}-4.6 \\
-3.6\end{array}$ & $\begin{array}{l}-12.7 \\
-11.1\end{array}$ & $\begin{array}{l}4.4 \\
4.5\end{array}$ & $\begin{array}{r}13.4 \\
4.5\end{array}$ & $\begin{array}{r}1.2 \\
-6.3\end{array}$ & $\begin{array}{l}27.1 \\
16.5\end{array}$ & $\begin{array}{r}-13.8 \\
-8.9\end{array}$ & $\begin{array}{l}-28.5 \\
-23.4\end{array}$ & $\begin{array}{l}3.9 \\
8.3\end{array}$ \\
\hline
\end{tabular}

*\% risk was significantly higher for those who died outside of a hospital or nursing home for Ischemic Heart Disease mortality (P value for interaction $<0.05$ ).

** Outside of hospital or nursing home ( $95 \%$ of these deaths occurred at residence) 

Figure 1: Locations for 48 monitoring sites (denoted by *) used to construct exposure estimates. Allegheny County is outlined in black. The Pennsylvania state boundary is shown in blue. Part of Lake Erie is shown in the northwest corner (top right). Major roadways are shown in orange. 
Figure 2. Monthly averages of pollutants, apparent mean temperature and cardiovascular mortality. Allegheny County, Pennsylvania (January $1^{\text {st }}$ 1999- December $31^{\text {st }} 2011$ )

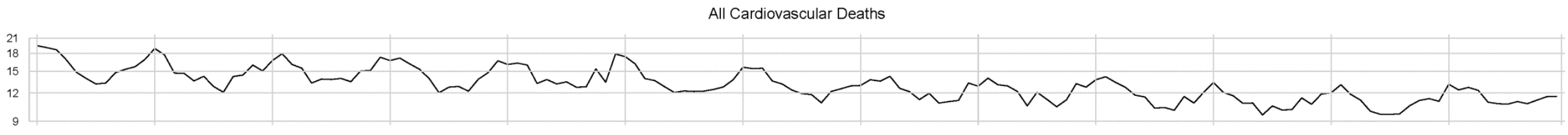

$\mathrm{PM}_{2.5}$ Mass Concentration $\left(\mu \mathrm{g} / \mathrm{m}^{3}\right)$
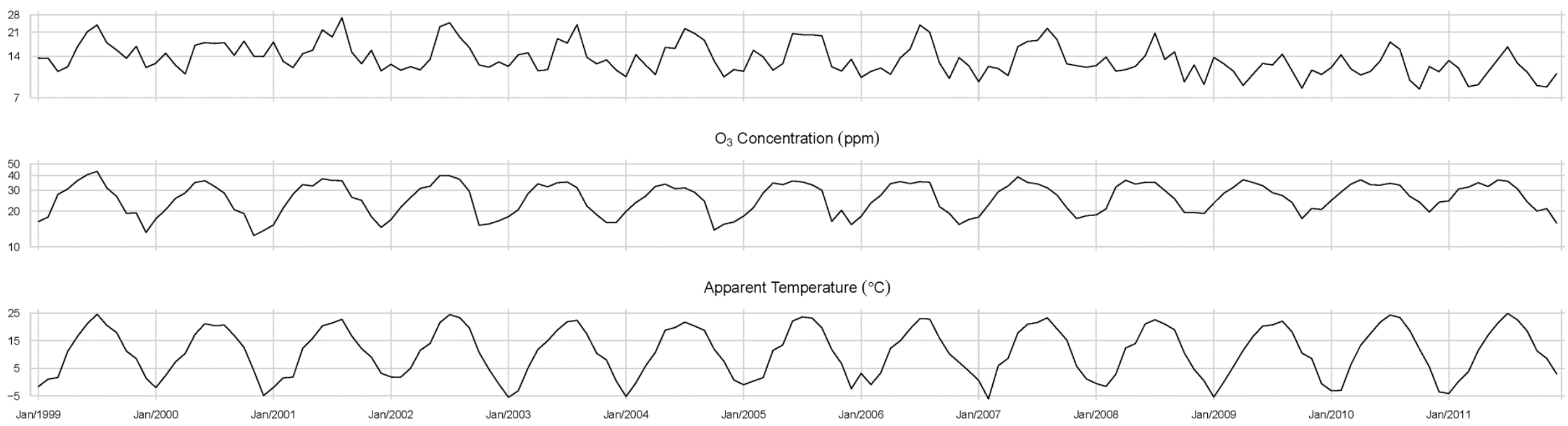
Figure 3. Percent change in risk (and $95 \%$ CI) of CVD mortality per $10 \mu \mathrm{g} / \mathrm{m3}$ - distributed lag models. Allegheny County, Pennsylvania (January $1^{\text {st }} 1999$ - December $31^{\text {st }} 2011$ ), (Adjusted for $\mathrm{O}_{3}$ and apparentmean temperature)
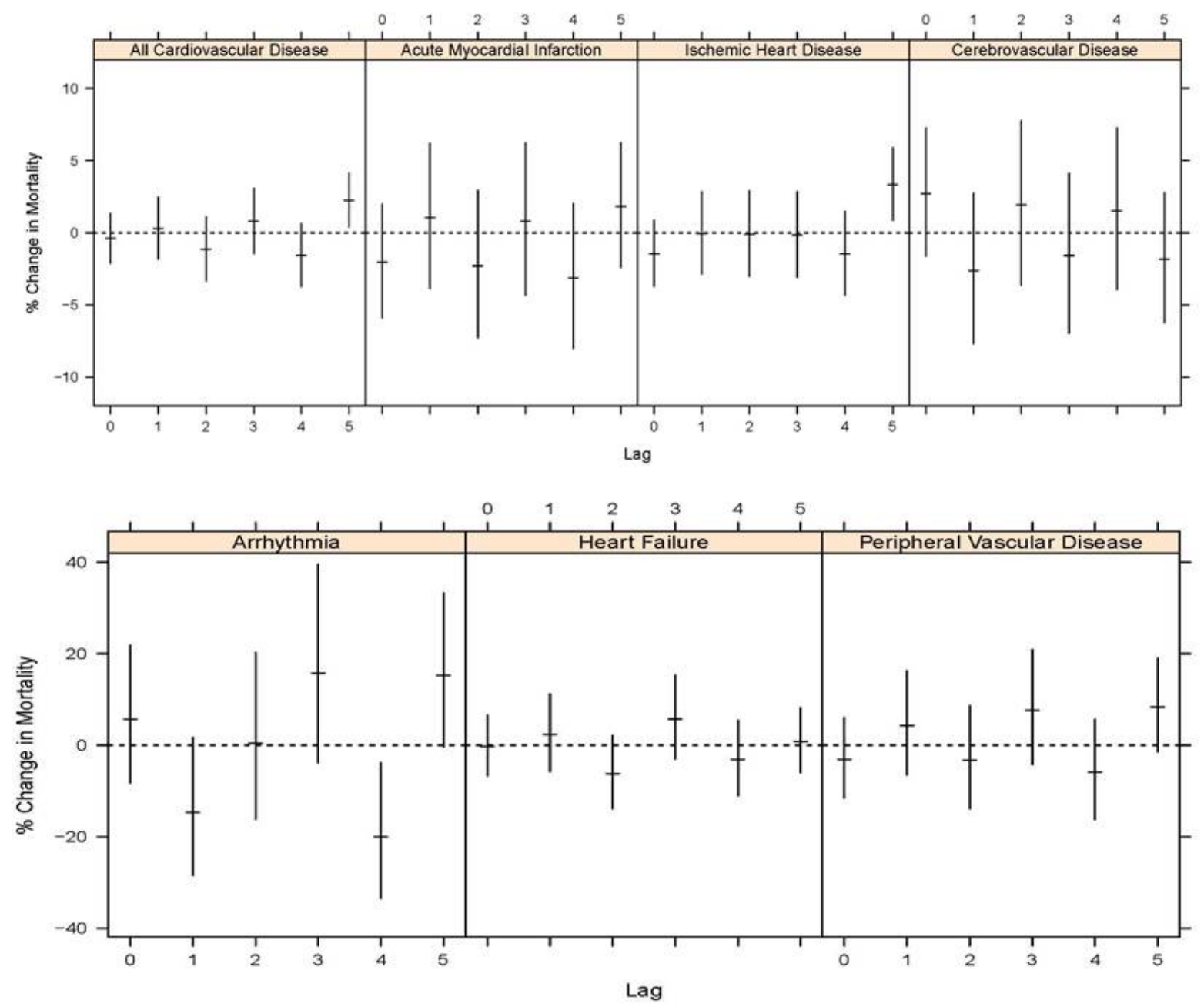